\title{
ArcheoSciences
}

Revue d'archéométrie

33 (suppl.) | 2009

Mémoire du sol, espace des hommes

\section{A short review of the use of geophysical prospection methods in Swedish archaeology}

Andreas Viberg, Immo Trinks and Kerstin Lidén

\section{OpenEdition}

1 Journals

\section{Electronic version}

URL: https://journals.openedition.org/archeosciences/1872

DOI: 10.4000/archeosciences.1872

ISBN: 978-2-7535-1599-4

ISSN: 2104-3728

Publisher

Presses universitaires de Rennes

\section{Printed version}

Date of publication: 30 October 2009

Number of pages: $375-378$

ISBN: 978-2-7535-0943-6

ISSN: $1960-1360$

\section{Electronic reference}

Andreas Viberg, Immo Trinks and Kerstin Lidén, "A short review of the use of geophysical prospection methods in Swedish archaeology", ArcheoSciences [Online], 33 (suppl.) | 2009, Online since 30 October 2011, connection on 01 February 2022. URL: http://journals.openedition.org/archeosciences/1872 ; DOl: https://doi.org/10.4000/archeosciences.1872 


\title{
A short review of the use of geophysical prospection methods in Swedish archaeology
}

\author{
Andreas Viberg *, Immo Trinks ${ }^{* *}$ and Kerstin LidÉN*
}

Key words: Archaeology, Geophysics, History, Sweden, Review.

\section{INTRODUCTION}

Geophysical prospection has a long history in Sweden, searching for ore bodies and investigating geology, connected to Sweden's long mining traditions. In archaeology the situation has been quite the opposite. Swedish archaeologists have generally been quite skeptic to use geophysical methods, and as a consequence only a handful geophysical prospection surveys has been conducted each year since the late 1970s. However the last years have seen a shift in the trend with an increasing use in archaeology. This abstract will briefly outline the major developments in archaeological geophysical prospection throughout the history of Swedish archaeology.

\section{GeOLOGICAL}

\section{AND ARCHAEOLOGICAL PRECONDITIONS}

The quaternary soil in Sweden is mainly dominated by glacial till which is the result of the last glacial period, Weichsel, in Northern Europe. As a consequence the soils in the landscape are predominated by non-sorted and highly heterogeneous glacial sediments or moraine. Clay soils are common in the central parts of Sweden as well as along the eastern coastal areas of the country. The moraine soils make both data collection and interpretation difficult and the clay areas prevent good depth penetration when using ground penetrating radar (GPR). Furthermore, Sweden has rather elusive and subtle prehistoric remains consisting mostly of postholes and hearths. The geology and the archaeology therefore present rather special challenges when working with archaeological geophysics.

\section{A BRIEF HISTORY OF GEOPHYSICAL PROSPECTION METHODS IN SWEDEN}

The 29th of July 1668 dates the first properly documented attempt to locate iron ore deposits with magnetic methods. It was performed with a simple declination compass by the prospector Jöns Persson (Carlborg, 1963:13). The knowledge of the compass' ability to locate iron ores was probably known in Sweden as early as the beginning of the 1640 s (Carlborg 1963:23). An early magnetometer, for the same purpose, was developed in Sweden in the late 19th century by Professor Robert Thalén (1879).

*Archaeological Research Laboratory, Stockholm University, Sweden. (andreas.viberg@arklab.su.se)

** UV-Teknik, Archaeological Excavation Department, Swedish National Heritage Board, Sweden. 
The first well documented attempt to use electrical equipotential methods for the location of ore bodies in Sweden can be traced to the year 1906. These surveys were executed with the method as outlined by Daft $\&$ William (Petersson, 1907). The method was however deemed to have to too many problematic (subjective) aspects and was therefore abandoned after a few attempts. Instead G. Bergström and F. Tegengren developed the method in the summer of 1913 (Bergström, 1913). Further developments of the equipotential method was made in 1918 by Hans Lundberg and Harry Nathorst who conducted several surveys (Fig. 1) with their new patent during the following years before Lundberg emigrated to Canada (Lundberg, 1919; 1922).

The first use of electromagnetic (EM) instruments to locate buried ore deposits was in 1921 by Centralgruppens Emmissons A.-B. (Sundberg et al., 1923:39). The survey used the EM method as developed by Karl Sundberg (Fig. 1) (Sundberg et al., 1923:18ff). The EM Slingram method was invented in Sweden in 1936 by Sture Werner and Alfred Holm (NE).

GPR was probably used for the first time in Sweden in 1976 (Nilsson, 1978).

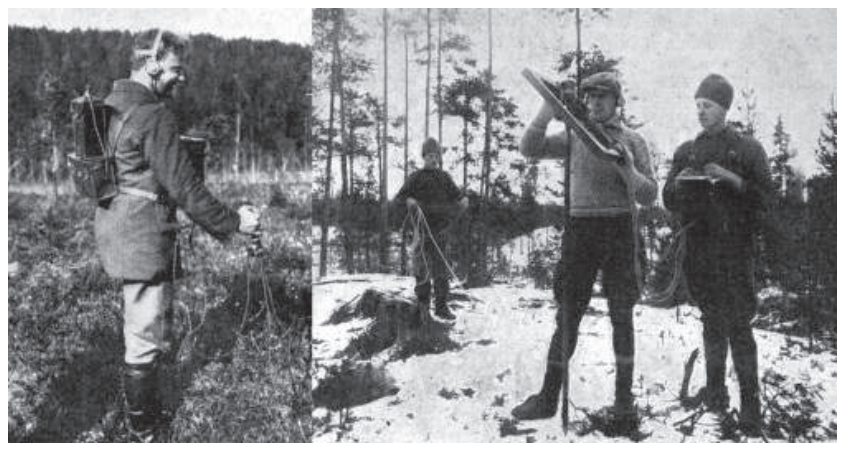

Figure 1: (left) An early Swedish equipotential mining survey, (right) Electromagnetic mining survey using the Sundberg method. Picture from Yearbook nr 17 of the Swedish geological survey (1923).

\section{HiSTORICAL USE OF GEOPHYSICAL METHODS IN SWEDISH ARCHAEOLOGY}

One of the pioneers in early geophysical archaeological prospection was the mining engineer Hans Lundberg. Lundberg is perhaps most famous for his career in mining geophysics but also made an impact on archaeological geophysics in North America after emigrating from Sweden (Bevan, 2000). Lundberg has for example been credited for the discovery of the Tepexpan man in Mexico using electrical methods (de Terra, 1947:41).
The first use of a geophysical method for archeological prospection in Sweden was in 1959 when a metal detector was used for examining the Iron Age peat bog site Skedemosse (Hagberg, 1961). Other geophysical methods were not used until the end of the 1970s when a collaboration between the Geological department at Chalmers University of Technology/University of Gothenburg and the Swedish National Heritage Board resulted in several electrical resistivity- and magnetometry surveys between the year 1977-1981 (Fig. 2) (Fridh, 1982). The geophysicist in charge was quite disappointed with the archaeologists involved in the project for not digging where he suggested.

The earliest $\mathrm{PhD}$ thesis in archaeological geophysics was published in 1980 (Fischer, 1980).

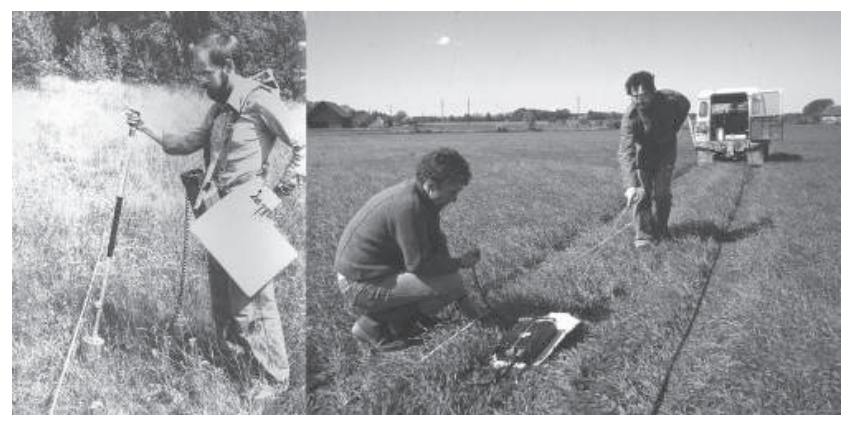

Figure 2: (left) Measurements with a proton-magnetometer at the Stone Age site in Gömme, Sweden. (C) Swedish National Heritage Board. (right) Early GPR measurements at the Stone Age site Ajvide, Gotland, Sweden. Photo: Göran Burenhult.

The first time GPR was used for locating buried archaeological remains in Sweden was in 1979 when Lund Technical University and the Swedish National Heritage Board investigated a Stone Age site in Skåne (Wihlborg \& Romberg, 1980). Other important early GPR surveys were carried out at the Stone Age sites of Skateholm, Skåne (Bjelm \& Larsson, 1984) and Ajvide, Gotland (Fig. 2) (Burenhult, 2002). Seismic methods have only been used once, 1992, in a survey of the Viking age town Birka (Andrén \& Lindeberg, 1997). Electromagnetic measurements with the EM-38 by Geonics were first used in the beginning of the 1990s when the Archaeological Research Laboratory (AFL) used the method when searching for a settlement connected to the boat grave burials in Vendel, Uppland, Sweden (Persson \& Olofsson, 1995). Other methods, such as magnetic susceptibility measurements for laboratory use, were first used in 1980 (Freij, 1980). 


\section{GEOPHYSICAL PROSPECTION IN CURRENT SWEDISH ARCHAEOLOGY}

The first surveys in Sweden were most commonly carried out by geophysical specialists with little or no experience in archaeology. Today several companies work exclusively with archaeological prospection and the number of surveys carried out every year has increased tremendously in the last couple of years. At present the Archaeological Research Laboratory is the only place for a university education in archaeological geophysics in Sweden, although several engineering programs in Sweden provide an opportunity to work with archaeological case studies. Another important development in archaeological geophysics has been the founding of a geophysical department at the Swedish National Heritage Board in 2005.

\section{ThE FUTURE OF GEOPHYSICAL PROSPECTION IN SWEDISH aRCHAEOLOGY}

The future of geophysical prospection in Swedish archaeology looks promising. The different geophysical methods are being used with increased frequency and developments towards faster motorized high resolution surveys are being initiated from different geophysical and archaeological prospection companies in Sweden (Fig. 3).

\section{ACKNOWLEDGEMENTS}

We would like to acknowledge Dr. Bruce Bevan, Professor D.S. Parasnis and Mr. Bernth Johansson (Malå Geoscience) for their valuable assistance.

\section{References}

Andrén, T. and Lindeberg, G., 1997. A Shallow Seismic Refraction Survey at Björkö, Eastern Sweden. In U. Miller, H. Clarke, A-M. Hansson, B.M. Johansson (dir.) Environment and Vikings. Scientific Methods and Techniques. Vol. IV, Riksantikvarieämbetet \& Statens Historiska Museer, Stockholm.

Bergström, G., 1913. Försök med Elektrisk Malmletning., P.A. Norstedt \& Söner, Stockholm.

BeVan, B., 2000. An early geophysical survey at Williamsburg, USA, Archaeological prospection, 7, (1): 51-58.

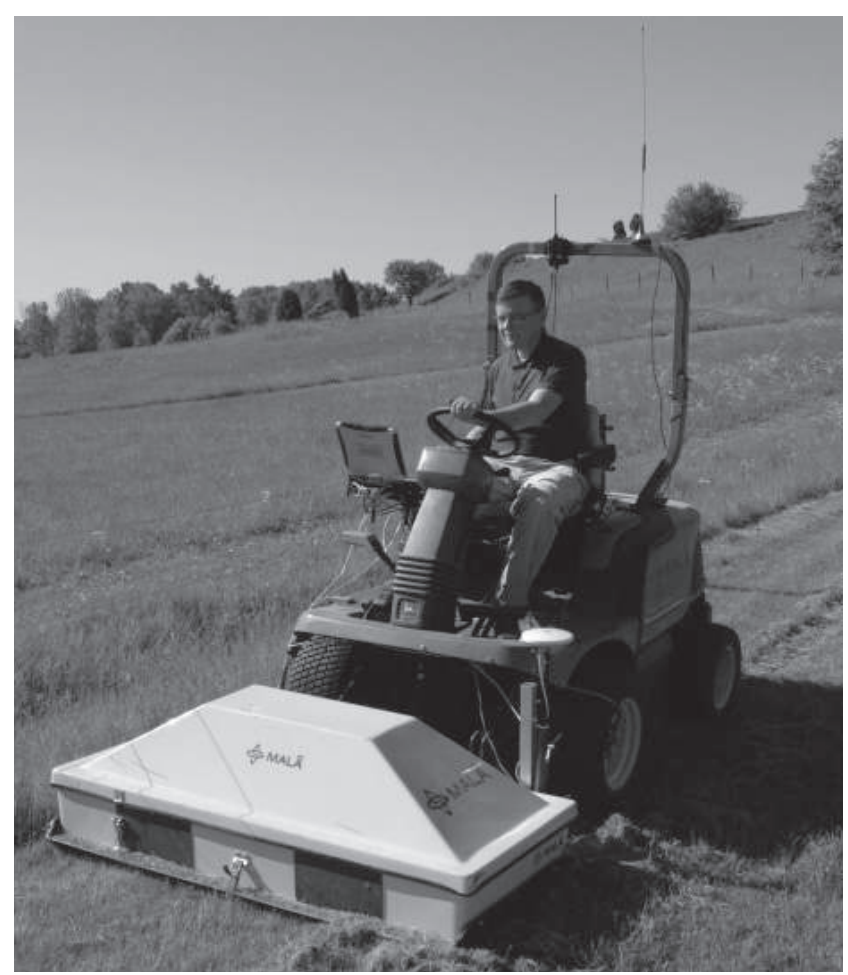

Figure 3: High resolution multi channel GPR survey using the Malå Imaging Radar System MIRA at the Viking age town Birka, Sweden 2008. Photo: Bernt Johansson Malå Geoscience.

Burenhult, G. and Brandt, B., 2002. The grave-field at Ajvide. In G. Burenhult (dir.) Remote sensing: applied techniques for the study of cultural resources and the localization, identification and documentation of sub-surface prehistoric remains in Swedish archaeology. Vol. 2, Archaeological investigations, remote sensing case studies and osteo-anthropological studies. Department of Archaeology, Stockholm University, Stockholm.

CarlborG, H., 1963. Om gruvkompasser, malmletning och kompassgångare. Sancte Örjens Gille, Stockholm.

Fischer, P. M., 1980. Applications of Technical Devices in Archaeology. The use of X-rays, microscope, electrical and electro-magnetic devices and subsurface interface radar. Thèse de doctorat, Göteborgs Universitet, Göteborg.

FREIJ, H., 1980. Förändring av markmaterial genom mänsklig påverkan, speciellt dess magnetiska egenskaper. C-uppsats, Arkeologiska forskningslaboratoriet, Stockholms Universitet, Stockholm.

FrIDH, B., 1982. Geofysiska metoder vid arkeologisk prospektering i Sverige. Geologiska institutionen, Chalmers tekniska högskola och Göteborgs universitet, Göteborg.

Hagberg, U. E., 1961. Skedemosse - En första presentation. Fornvännen, $56: 237-255$. 
LuNDBERG, H., 1919. Potentialmetod för elektrisk malmletning. Jernkontorets Annaler, Femte häftet, 203-215.

LundBerg, H., 1922. Practical Experience in Electrical Prospecting. P.A. Norstedt \& Söner, Stockholm.

NiLsson, B., 1978. Two topics in electromagnetic radiation field prospecting. Thèse de doctarat, Department of Civil, Mining and Environmental Engineering, Applied Geophysics. Luleå University of technology, Luleå.

Persson, K. and Olofsson, B., 1995. Kan modern teknik avslöja var båtgravsfolket bodde? Populär arkeologi, 1: 12-13.

Petersson, W., 1907. Om malmsökande medelst elektricitet. Jernkontorets Annaler, 2-3 : 153-171.
Sundberg, K., Lundberg, H. and Eklund, J., 1923. Electrical Prospecting in Sweden. Årsbok 17, Sveriges Geologiska Undersökning, Stockholm.

de Terra, H., 1947. Preliminary note on the discovery of fossil man at Tepexpan in the Valley of Mexico. American Antiquity, $13: 40-44$.

ThaléN, R., 1879. Om undersökning afjernmalmfält medelst magnetiska mätningar. Akad. bokh., Upsala.

Winlborg, A. and Romberg, T., 1980. Georadar för att spåra fornlämningar? Medeltidsarkeologisk tidskrift (META), 4: 33. 